\title{
ФУНКЦИОНАЛНОСТ ПАРТИКУЛА У РАЗГОВОРНОМ ДИСКУРСУ
}

\begin{abstract}
Партикуле, као јединице прагматичког нивоа, представљају факултативне чланове исказа, а њихова основна функција јесте функција модификације, која се најчешће реализује као комуникативно, градуативно или емотивно-експресивно појачавање. Партикуле имају важну улогу и у процесу организовања дискурса, при чему се ове јединице јављају као конектори, односно као формални показатељи смисаоних односа у дискурсу. У овом раду, чији корпус чине интернет-форуми на српском језику, испитујемо функционалност партикула у разговорном дискурсу управо са прагматичког и текстуалнолингвистичког аспекта.
\end{abstract}

Кључне ријечи: партикула, ријечца, интензификатор, конектор, разговорни дискурс.

1.0. У овом раду испитује се улога партикула у специфичном типу дискурса, какав је разговорни. Овако постављена тема најприје изискује објашњење термина партикула и одређење појма разговорни дискурс, пошто у домаћој науци о језику ставови о овим проблемима нису усаглашени.

1.1. Партикуле, на примјер, поједини аутори терминолошки изједначавају са ријечцама (в. Мразовић 22009 , Ристић 1999), док други (уп. нпр. Ковачевић 1998, Јањушевић Оливери 2018) сматрају да су партикуле подврста ријечци и да тек са модалним ријечима чине ријечце као врсту ријечи. Терминолошка неусаглашеност при одређењу партикула и/или ријечци отежава и могућност њиховог дефинисања, тим прије што је ове јединице немогуће издвојити као врсту ријечи на основу уобичајених морфолошких и синтаксичких критеријума.

Како је већ уочено (Половина 1999: 78, Бадурина 2008: 26), ријечце/партикуле је могуће препознати и правилно идентификовати тек на нивоу текста, односно дискурса, и то на основу њихове прагматичке вриједности. Тако 
се ријечце могу одредити као елементи дискурса/текста који, с једне стране служе за модификовање исказа, а са друге - дјелују као формални показатељи (смисаоних) односа у дискурсу.

Сам појам модификације је веома широк, а он, када су у питању ријечце, подразумијева макар три типа, и то: (1) наглашавање исказа или његовог дијела, (2) мијењање комуникативног типа исказа с обзиром на истинитосну вриједност предиката и с обзиром на аспекат пружања или тражења информације (изјавност/упитност) и (3) изношење става говорног лица према неком од елемената говорног чина. С обзиром на тип остварене модификације, ријечце је оправдано подијелити на партикуле, које карактеришу прва два типа модификације, и на модалне ријечи, којима се искази из индикативности преводе у модалност. ${ }^{1}$ Из овог произлази да се и унутар саме класе партикула могу издвојити поткласе, и то: интензификаторске партикуле, које чине већину, ${ }^{2}$ упитне партикуле и потврдне и одричне партикуле. Ово истраживање ограничићемо на улогу интензификаторских партикула у модификовању и обликовању разговорног дискурса.

1.2. Под разговорним дискурсом ћемо у овом раду подразумијевати неформални вид свакодневне језичке комуникације, који може бити остварен не само усменим него и писменим путем, под условом да га одликују спонтаност, дијалогичност, флексибилност у погледу поштовања норме, али и употреба експресивних језичких средстава. Нарочит степен експресивности у овом типу дискурса носи његова лексика, у коју, свакако, спадају и партикуле.

1.3. Као корпус за овај рад послужиле су четири форумске теме - Да ли ваш вереник, муж, дечко... зна да кува; Право време за брак; Да ли сматрате да је батина из раја изашла и да ли бијете своју деиу и Може ли закон да васпитава нашу деиу - као и коментари новинског чланка Стари студенти се позивају на своја права, објављеног у Политици. Концепција форума и новинских коментара заснива се на дијалогу, који може тећи у више праваца. Наиме, дијалог подразумијева изражавање става у вези са постављеном темом, али се у овим типовима дискурса може полемисати и са туђим ставовима.

2.0. Управо дијалошка природа разговорног дискурса отвара могућност употребе разноврсних интензификаторских партикула, које се, генерално, могу подијелити у три групе. ${ }^{3}$ Првима се издваја комуникативно најважнији елеменат на плану контекста, и то су ас еверативне партикуле у ши рем смислу, а обухватају асеверативно-фактивне, пресупозицијске, рестриктивне и адверзативно-конщесивне партикуле. Другом типу припадају градуативне партикуле, које истичу степен заступљености особине,

\footnotetext{
${ }^{1}$ На основу ових критеријума, Л. Бадурина (2008: 30) разликује 'праве честице' - да, не, ли и зар, које „,mijenjaju rečeničnu predikaciju od afirmacije do negacije, od potvrdnosti u upitnost” и модалне ријечи које реченицу мијењају „od indikativnosti u modalnost”.

2 У студији о интензификаторским партикулама издвојили смо чак 84 овакве јединице - в. Јањушевић Оливери 2018.

${ }^{3}$ В. и класификацију интензификаторских партикула у Јањушевић Оливери 2018.
} 
док трећу групу чине ем фати чке партикуле, чија је функција експресивно-емотивно наглашавање исказа или његовог дијела.

2.1. Међу партикулама првог типа најразноврсније су у разговорном дискурсу асеверативно-фактивне партикуле, а наш корпус пружа потврде за интензификаторе баш, управо, заиста, стварно, просто, и то и у ствари.

Партикулама баш и управо наглашава се да се реченична предикација тиче издвојеног појма, а не неког другог. Сличну улогу има и перифрастичка партикула $u$ mо, којом се најчешће наглашава зависни члан синтагме:

(1) Ma, nekuva UOPSTE [...] ali ne smeta mi to, da ja budem glavna u kuhinji... ostale poslove ne delimo.... ma volim ga ja svakako,bas takvog.... (Женски свет 1); ${ }^{4}$ Materijalna sigurnost je vazna u braku i svi to znamo, a mnogi brakovi krahiraju upravo zbog lose finansijske situacije. (Женски свет 2);

(1a) Zna da kuva i to dosta dobro. (Женски свет 1)

Партикуле заиста, стварно и просто, осим што комуникативно наглашавају предикат, истичу и истинитост тврдње изнијете исказом. У истој, припредикатској позицији и са истом вриједношћу могу бити употријебљене и партикуле $u$ и баш:

(2) E sad, ja stvarno mislim da su duže veze pre braka poželjne, pa čak i zajednički život, jer tako zaista imamo priliku da upoznamo svog partnera i da znamo šta nas sve u zajedničkom životu očekuje. (Женски свет 2); Kod mene u kuci je glavni kuvar moj muz. [...] On prosto obozava da kuva i to radi perfektno. (Женски свет 1);

(2à) Brak je jako komplikovana stvar sa bezbroj finesa i poteskoca, tako da samo prava ljubav uspeva da premosti sve! [одговор] Da, u pravu si, brak i jeste komplikovana stvar. (Женски свет 2); [...] rekao mi je - ma, ovako ti je bolje, vidi da ima celuloze u ljusci, to ti je dobro za varenje... ovo ti je još i zdravije.... [одговор] Haha zveko bas je dobar. (Женски свет 1)

Партикула у ствари, која је само једном потврђена у корпусу, има нешто другачију вриједност - њоме се коригује претходно изнијета информација, и у систему партикула јој је најближи интензификатор заправо, за који немамо потврде на прегледаним страницама. Забиљежено је, међутим, више примјера (укупно пет) са партикулом $u$ у овој функцији, што говори о томе да је за разговорни дискурс као партикула са корективном интензификаторском функцијом резервисана партикула $u$.

(26) Zna da kuva, ali to je uglavnom ono nesto najosnovnije, a inace ne kuva jer nece....u stvari da ne lazem hoce ali jaaaako retko (Женски свет

\footnotetext{
${ }^{4}$ Примјере наводимо у оригиналном облику, дакле, са правописним грешкама, карактеристичном интерпункцијом, те употребом великог и малог слова. Наше интервенције тичу се уклањања емотикона и успостављања начина истицања - болдом је обиљежена партикула, а италиком елеменат исказа који је наглашен.
} 
1); Nikada brak nije uspeo koji i postoji samo radi papira i formalnosti! (Женски свет 1).

Партикуле баш, стварно и заиста у нашој грађи имају приближно једнаку заступљеност (по осам, односно девет потврда), ${ }^{5}$ док управо има дупло мању фреквенцију, за којом слиједе партикуле $u$ то, просто и у ствари. Овакав однос у погледу заступљености асеверативних партикула је и очекиван, јер су интензификатори баш, заиста/стварно репрезентативни представници ове врсте партикула и карактеристични су за све типове дискурса, док су партикуле управо, и то и у ствари одлика публицистичког и научног дискурса, преко којих су, вјероватно, и доспјеле у објаве на форумима. Оно што је неуобичајено и неочекивано у овом типу дискурса јесте већа фреквенција партикуле $u$, којој наглашавање истинитости тврдње није примарна функција.

2.1.1. Типична прагматичка вриједност партикуле $u$ јесте истицање једног од појмова чије присуство у свијести учесника говорног чина пресупонира постојање и других појмова обједињених неком заједничком карактеристиком. Партикулом $u$, односно њеном одричном варијантом ни, резервисаном за одричне исказе, уз незнатан утицај на значење исказа, могу се супституисати и друге пресупозицијске партикуле. Као таква, ова партикула је доминантна у разговорном дискурсу, а уз њу су потврђени, са неупоредиво нижом фреквенцијом, и пресупозицијски интензификатори такође, још и чак:

(3) Moj zna da sprema i zimnicu,pogotovo ajvar,da pojedes i teglu (Женски свет 1); Moj ne kuha, i meni je to sasvim ok. Ne volim da mi se bilo ko petlja u kuhinju; [одговор] Nevolim ni ja bas da mi se petlja u kuhinju, mnogo sudova isprlja... (Женски свет 1); Mi nismo na teretu drzave, vec sami placamo sve. Profesori postoje. Rokovi i literatura takodje. Za svaki ispit sam kupila novu literaturu, polagala sa bolonjcima. Nijedan profesor nije rekao da smo mi smetnja. Cak tvrde da mi bolje naucimo od bolonjaca. Za nas još jedan produžetak na samom kraju je naša pobeda i pobeda naših porodica i samog društva kao celine. (Политика).

2.1.2. У разговорном дискурсу су евидентиране и партикуле чије је основно значење сужавање, односно рестрикција. Уз типични рестриктор само, забиљежена је и партикула једино.

(4) A sto se tice pravog vremena, jedino pravo je ono kad pronadjes pravu osobu i nista drugo! [...] Brak je jako komplikovana stvar sa bezbroj finesa i poteskoca,tako da samo prava ljubav uspeva da premosti sve! (Женски свет 2).

Са рестриктивном вриједношћу, уз информацију да издвојени појам представља задовољавајући минимум, у корпусу су регистроване партикуле макар и бар:

\footnotetext{
${ }^{5}$ У раду, због ограниченог простора, наводимо по један или евентуално два карактеристична примјера за сваку од партикула.
} 
(4a) Ali recimo dok sam radila duze od njega uvek je imao dobru volju da nesto sprcka - makar najjednostavnije, al znaci!!! (Женски свет 1); Postoji li roditelj koji bar jednom nije tako nahranio dete ili mu dete nije prespavalo u krevetu? (Бебац).

2.1.3. Партикулама са функцијом наглашавања комуникативно најважнијег елемента исказа припадају и адверзативно-концесивне ријечце ипак и onem, које се од осталих јединица ове врсте разликују по томе што уравнотежују међусобно супротстављене садржаје.

(5) [...] Sto se tice doba u kom bi trebalo stupiti u brak, ja bih samo govorila o donjoj granici Neko ko ima 15 ili 16 godina ipak je jos uvek dete $u$ svojoj biti i ma koliko da ima iskustva u zivotu, ipak mislim da ne moze u potpunosti shvatiti odgovornosti i obaveze koje brak nosi. (Женски свет 2) [...] Ja stvarno vjerujem da vrlo malo roditelja ide svjesno da nanese fizičku bol svom djetetu, ali ih opet kvrcne po guzi i kaže ma ne boli to ništa! Kakav onda efekat ima to kvrcanje po guzi? (Бебац).

2.2. Осим партикула које служе за истицање комуникативно најважнијег елемента исказа, у разговорном дискурсу је очекивана и употреба јединица којима се истиче степен заступљености особине. Међутим, сакупљени корпус је показао да такве партикуле имају сужену употребу, а да њихову прагматичку вриједност преузимају прилози (јако, много, апсолутно) који као секундарну могу имати и функцију градуативног појачавања. Регистровано је неколико примјера употребе типичних градуативних партикула врло и веома, као и партикуле све и још, које појачавају компаративни степен:

(6) Prosto svako od nas ima svoju vrlo subjektivnu i veoma objektivnu pricu i razlog produzenog studiranja. (Политика);

(6a) Imam 23 godine, dugu vezu, planove...ali sto sam starija, sve se teze usudjujem na taj korak, nekako se plasim mnogih stvari koje brak donosi. (Женски свет 2); Upravo se prelaskom na Bolonju studije produzavaju jos vise. Sta je onda cilj ministra, da duge studije jos vise produzi, pricajuci da je dugo studiranje problem? (Политика).

У разговорном дискурсу се јавља и перифрастичка градуативна партикула $u$ mе како којом је могуће наглашавати и предикат, имајући притом у виду нарочит начин вршења радње:

(6б) Itekako zna da kuva, sve on to polako, pa isprobava, od nicega svasta napravi. Jedino ostavi brdo sudova, pa dok se snadjem u kuhinji... (Женски свет 1).

2.3. За разлику од градуативних партикула, чија је фреквенција у анализираном корпусу сразмјерно ниска, једна од доминантних карактеристика разговорног дискурса јесте употреба партикула којима се емотивно-експресивно, односно емфатички истиче цијели исказ или неки његов дио. Управо разговорни дискурс омогућава издвајање овог типа партикула, због чега их П. Мразовић (2009) назива конверзационима. Ми се, због њихове прагматичке вриједности, ипак опредјељујемо за термин емфатичке партикуле. 
На прегледаним интернет-страницама забиљежена је партикула $n a$, сама и у комбинацији са партикулом још, затим партикуле само, хајде, бре, ма, e, које такође служе са ескпресивно-емотивно истицање исказа или његовог дијела.

(7) Ne slazem se zakonom, pa skoro uopste. (Бебац) Pa samo u mom okruzenju ima primera gde su deca bas zanemarena u svakom smislu, i niko nista..... Zakon, pa jos takav. (Бебац);

...kad se samo setim - jednom sam imala neki grip i zamolim ga da mi donese beli luk da jedem...kad on doneo beli luk u ljusci... (Женски свет 1)

E pa, ovo je stvarno mucenje za ljude. Pustite ih, ne izmisljajte kojekakve stvari. Odlaze mladi, prazni se Srbija. Ajde naterajte i ove da odu! (Политика);

Ma batina bre. Da su mene roditelji barem malo bili, msm da bih bila bolja sto se tice ponasanja prema njima...I skole (Лептирица).

Иако наша грађа не пружа потврду за њих, у овом типу дискурса се јављају и многе друге партикуле које емотивно-експресивно појачавају исказ, нпр. ама, ала(j), та, етички датив, емфатички акузатив итд. (в. Јањушевић Оливери 2018). Типична позиција већине емфатичких партикула јесте иницијална, што им и отвара могућност да улози експресивно-емотивног појачавања придодају и улогу дискурсних конектора. ${ }^{6}$

3.0. Већ је у литератури скретана пажња на улогу ријечци у обликовању текста или дискурса (Ристић 2004, Бадурина 2008, Чудомировић 2009). У досадашњим истраживањима узимане су у обзир углавном модалне ријечи и њихова кохезивна улога, док се на такву улогу партикула само спорадично указивало. Разлог томе је, свакако, и непостојање јасног критеријума за диференцирање партикула од везника, са једне, и од узвика, са друге стране.

Полазећи од одређења партикула које смо дали у уводу, у наставку истраживања приказујемо партикуле које у разговорном дискурсу служе не само за наглашавање него и за прецизирање смисаоних односа у дискурсу. Ту се, када је у питању разговорни дискурс, у првом реду издваја класа емфатичких партикула, а као кохезивно средство могу бити употријебљене и неке од партикула које примарно служе за комуникативно наглашавање исказа.

3.1. Међу емфатичким партикулама улогу конектора у разговорном дискурсу најчешће имају партикуле $n a$ и $e$, а у истој улози се, у нашем корпусу, јавља још и партикула $м a$, као и емфатички употријебљена партикула $u$.

(8) pa jeste izasla iz raja naravno, mada se sve moze rijesiti i razgovorom (Лептирица);

Ja to uradila sa celih 30 godina. Za mene to bilo pravo, jer sam tek tada nasla Pravog. Zao mi jedino zbog dece sto nisam ranije. [одговор] Pa dobro, kazu da je najbolji period za radjanje dece izmedju 25 i $35 \ldots$ (Женски свет 2);

\footnotetext{
${ }^{6}$ С. Ристић (2004: 508) под дискурсним конекторима, у које, поред партикула, спадају и везници и прилози подразумијева „експоненте кохезије семантичког типа”, који служе за повезивање прагматичких и когнитивних садржаја дискурса.
} 
Ma batina bre. Da su mene roditelji barem malo bili,msm da bih bila bolja sto se tice ponasanja prema njima... I skole (Лептирица);

Moj zna da sprema i zimnicu, pogotovo ajvar, da pojedes i teglu, [одговор] $\mathbf{E}$, moj to jos nije probao, jer nam uglavnom sprema moja majka. (Женски свет 1);

(9) Naravno da se pozivamo na svoja prava!!Pa valjda smo pravna drzava a ne kameno doba! (Политика);

I ja sam takva. On donese od mame (njegove) pitu, i hvali je na sav glas, pa ja onda brže bolje sutradan napravim i slatku i slanu, samo da i moju hvali Ma, prepredeni su oni, namerno to rade (Женски свет 1);

Moj muz zna sve da sprema cak me nekim stvarima naucio..a sada samo ja kuvam, jedino rostilj e tu je glavni...iskreno vise volim ja da sam glavna sto se tice kuvanja.... (Женски свет 1);

(...) Ima dosta ljudi koji su socijalni slučajevi, moje komšije na vikendici npr nemaju u kuci WC, djecu tušira u velikoj banjici grijući vodu na šporetu i slično, djeca su joj kulturna, vaspitana, izuzetno uredna i odlični učenici. „E sada pošto oni nisu djeci obezbjedili, osim velike ljubavi, pažnje, razumjevanja i vaspitanja ništa drugo" njima treba oduzeti djecu jer eto nemaju, konkretno taj wc! (Бебац);

Mislim da će ovo biti debelo zloupotrebljeno. Mada mi kao država se busamo u grudi kako donosimo promene, e pa neke stvari ne treba menjati. (Бебац).

Иницијалним $n a^{7}$ и $м a$ у дијалошкој реплици потврђује се туђи претходно изнијети став (у оба наведена примјера тај став је оличен у пословици Батина је из раја изашла), док се партикулом $е$ на почетку реплике супротставља њен садржај претходећим тврдњама саговорника. Уз партикулу па на почетку реплике често се употребљава и прилог добро, чиме се још јасније истиче однос сагласности. Исту вриједност ове партикуле имају и као дискурсни конектори у склопу реплике (примјери 9). Партикула $e$, поготову када је праћена партикулама $c a d a^{8}$ и $n a$, изражава однос контраста и супституентна је конектором али.

И партикула $u$, употријебљена на почетку исказа са циљем да истакне чуђење или негодовање говорног лица поводом пропозиције, поред интензификаторске, има и улогу дискурсног конектора. Примјер (10) показује да се такво $u$ може наћи и на почетку (реторичког) питања, али, по нашем мишљењу, исказ са емфатичким $u$ би морао имати узвичну интонацију, иако дискутант на форуму није тако обиљежио своје исказе.

\footnotetext{
${ }^{7}$ Иако уочава да се $n a$ у овој позицији не понаша на идентичан начин као хомоформни му везник, као и да уноси експресивност у исказ, Чудомировић (2015: 175-177) овакво па сматра везником.

${ }^{8}$ Ријечцу сад Ј. Чудомировић (2009: 291) такође третира као текстуални конектор и напомиње да се она често употребљава у склопу конекторских исказа e cad, a cad, u cad.
} 
(10) Hoce li to biti nesto na ovu foru?

Error! Hyperlink reference not valid.

I da li mislite da je ovo tacno.? Pa sve i da jeste prilicno je glupavo. Postoji li roditelj koji bar jednom nije tako nahranio dete ili mu dete nije prespavalo u krevetu? I za to se oduzimaju deca... (Бебац).

3.2. И пресупозицијске партикуле, захваљујући свом значењу проширивања, видљиви су сигнали контекстуалне укључености исказа. Међутим, улогу правог дискурсног конектора, којим се експлицира природа везе међу дијеловима текста, има партикула такође, и то када се нађе у иницијалној позицији исказа или реплике.

(11) Zanimljivo je, da je ministar gospodin Šarčević isticao i kako će pre prelaska na Bolonju biti jasno definisani uslovi prelaska [...] Takođe treba se setiti i ostalih izjava ministra gospodina Šarčevića datih pre samo godinu dana. (Политика); Moj suprug ume da kuva,voli da kuva razna jela, narocito voli da nas iznenadi sa kineskom hranom, riblju corbu bolje kuva od mene moram priznati. [...] [одговор] Takodje anaana i moj isto tako...pravi kinesku hranu, riblju corbu, mesi pizzu i hleb. Sve to su njegovi specijaliteti i ja se u njih nemesam. (Женски свет 1);

(11a) Ne slazem se zakonom, pa skoro uopste. [...] Takodje, skoro sam citala jedan clanak koji ima doticnih tacaka sa ovim o cemu ovde pricamo i mislim da je jako lepo napisan, i predocava neke stvari koje, mozda, i nisu tako lake za uocavanje. (Бебац).

Како је већ утврђено, „конектор такође означава да садржај који следи представља наставак претходног садржаја, који се њиме проширује у истом смеру" (Чудомировић 2009: 291). Међутим примјер (11а) показује да такође може бити употријебљено као конектор који само најављује проширивање дискурса, при чему његов наставак може донијети и нову тему. С обзиром на то да је у исказима наведеним под (11) са истом прагматичком вриједношћу проширивања употријебљена партикула $u$, ријечца такође, са семантичко-прагматичког аспекта, представља плеоназам. С друге стране, као дискурсни конектор, она олакшава рецепцију текста.

И партикуле засноване на значењу сужавања могу бити видљиви знаци смисаоних односа у дискурсу. У тој улози, са по једним примјером, у нашем корпусу су забиљежене партикуле само и једино, при чему се њихово значење рестрикције претвара у значење релативизовања: ${ }^{9}$

(11) Zna da kuva i to dosta dobro. Samo nema baš vremena za to, tako da sam glavni kuvar (Женски свет 1); Itekako zna da kuva, sve on to polako, pa isprobava, od nicega svasta napravi. Jedino ostavi brdo sudova, pa dok se snadjem u kuhinji... (Женски свет 1).

\footnotetext{
9 Чудомировић, поред овог, наводи и значење оспоравања, када је у питању конектор само (Чудомировић 2009: 291).
} 
Најближи синоним партикулама само и једино у наведеним примјерима јесте адверзативни везнички конектор али.

Улогу релативизатора садржаја изнијетог претходним исказом има и адверзативна партикула међутим, која је једном потврђена у нашем корпусу:

(12) Ranije sam mislila da je pravo vreme za zenu 26 do 28 godina... Chak sam mislila i shto kasnije - to bolje. Medjutim, sad mislim da je pravo vreme za brak onda kad se nadje prava osoba, kad god to bilo, jer mozda ce u vreme koje mi smatramo pravim naici pogreshna osoba... (Женски свет 2).

4. На основу прегледа грађе, чији смо само дио навели у овом раду, закључујемо да су у разговорном дискурсу најразноврсније асеверативно-фактивне и емфатичке партикуле. Анализа је уз то показала да поједине партикуле, у зависности од контекста у коме су употријебљене, могу имати различите прагматичке вриједности, што свједочи о томе да су у питању „функцијске јединице", које немају лексичко, већ прагматичко значење.

4.1. С обзиром на то да се разговорни дискурс темељи на размјени ставова, при чему је поједине дијелове потребно нагласити или пак истаћи истинитост изнијетих тврдњи, сасвим је очекивана и оправдана употреба партикула асеверативно-фактивног типа. Овај вид комуникације захтијева и повезивање елемената обједињених истом карактеристиком, при чему се на плану контекста једни елементи истичу, а други се подразумијевају, те је испитивани тип дискурса отворен и за пресупозицијске партикуле. Осим ових, у разговорном дискурсу евидентирана је и употреба рестриктора само који је сличан како асеверативним, тако и пресупозицијским партикулама, јер се њиме на фону контекста истиче елеменат исказа који је, у односу на сличне елементе, издвојен посједовањем неке карактеристике. Најнижу фреквенцију имају партикуле адверзативно-концесивног типа.

У овом типу дискурса ријетке су и градуативне партикуле, а разлог томе јесте употреба конкурентних средстава - прилога (јако, много, апсолутно), којима се такође може истицати степен заступљености особине.

Разговорни дискурс као тип комуникације који се одликује дијалогичношћу, експресивношћу и спонтаношћу омогућава употребу јединица којима се емотивно-експресивно наглашава исказ или његов дио. Такве партикуле, које смо назвали емфатичкима, модификују илокутивни аспект исказа, уносећи у њега значења неочекиваности, противљења, убјеђивања итд.

4.2. Емфатичке партикуле се употребљавају и у улози дискурсних конектора. Посебну важност за уобличавање дијалога као јединственог дискурса имају партикуле које се налазе на почетку реплике. Као текстуални конектори, емфатичке партикуле указују на то да су дијелови дискурса међусобно у односу сагласности (мa, na) или супротстављања (e).

Партикуле чија је примарна функција истицање комуникативно најважнијег елемента, када су употријебљене као текстуални конекотри, изражавају односе проширивања претходног исказа или реплике (такође) и релативизовања претходног садржаја (само, једино, међутим). Прегледом грађе смо 
утврдили да су ови конектори прилично ријетки у разговорном дискурсу, јер су их, по свој прилици, истиснула друга конкурентна средства. На примјер, најчешћа партикула не само разговорног него и било ког другог типа дискурса - партикула $u$ - у стању је да искаже односе који се обиљежавају дискурсним конектором такође. С друге стране, односи релативизовања, контрастирања или, најшире узето, супротстављања - у разговорном дискурсу се везују за везничке конекторе али и $a$, којима обилују и прегледане интернет-странице.

\section{ИЗВОРИ}

Бебац: https://www.bebac.com/forum/index.php?/topic/3224-mo\%C5\%Bee-li-zakonda-vaspitava-na\%C5\%A1u-decu/ 18. VIII 2019.

Женски свет 1: https://www.zenskisvet.com/forum/tema/925-2/Da-li\%E2\%80\%94on. html 17. VIII 2019.

Женски свет 2: https:/www.zenskisvet.com/forum/tema/2-1/Pravo-vreme-zabrak.html 17. VIII 2019.

Лептирица: https:/www.leptirica.com/forum/moja-porodica-24/da-li-je-batinaiz-raja-izasla/ 18. VIII 2019.

Политика: http://www.politika.rs/scc/clanak/436149/Stari-studenti-se-pozivajuna-svoja-prava\#komentari 22. VIII 2019.

\section{ЛИТЕРАТУРА}

Бадурина 2008: L. Badurina, Između redaka. Studije o tekstu i diskursu, Zagreb: Hrvatska sveučilišna naklada; Rijeka: Izdavački centar.

Јањушевић Оливери 2018: А. Јањушевић Оливери, Интензификаторске партикуле у савременом српском језику, Косовска Митровица: Филозофски факултет; Никшић: Матица српска - Друштво чланова у Црној Гори.

Ковачевић 1998: М. Ковачевић, Диференцијација партикула и хомоформних (дијелова) везника, у: М. Ковачевић, Синтакса сложене реченице у српском језику, Београд: Рашка школа, 246-257.

Мразовић 22009: P. Mrazović [u saradnji sa Zorom Vukadinović], Gramatika srpskog jezika za strance, Sremski Karlovci - Novi Sad: Izdavačka knjižarnica Zorana Stojanovića.

Половина 1999: V. Polovina, Semantika i tekstlingvistika, Beograd: Čigoja štampa.

Ристић 1999: С. Ристић, Партикуле и њихови функционални еквиваленти, у: С. Ристић, М. Радић-Дугоњић, Реч. Смисао. Сазнање, Београд: Филолошки факултет, 93-117.

Ристић 2004: С. Ристић, Партикуле као јединице семантичке кохезије, Cpnски језик, IX, 505-514. 
Чудомировић 2009: Ј. Чудомировић, Речце као текстуални конектори у савременом српском језику, Книжевност и језик, LVI/3-4, 277-295.

Чудомировић 2015: J. Чудомировић, Семантика и прагматика саставних одн. супротних напоредних везника $u, n a, m e, a$, али, него [докторска дисертација], Београд: Филолошки факултет http:/nardus.mpn.gov.rs/ bitstream/handle/123456789/4868/Disertacija495.pdf?sequence=1\&isAllow ed=y 20. VIII 2019.

Анна М. Янюшевич Оливери

ФУНКЦИОНАЛЬНОСТЬ ЧАСТИЦ В РАЗГОВОРНОМ ДИСКУРСЕ

\section{Резюме}

Частицы, как единицы прагматического уровня, представляют собой факультативные члены высказвания, основной функцией которых является функция модификации, реализуемая как коммуникативное, градуативное или эмоционально-экспрессивное усиление. Частицы играют важную роль также в процессе организации дискурса, причем данные единицы встречаются в виде коннекторов, точнее - формальных показателей смысловых отношений в дискурсе. Анализ, проведенный в данной работе, показал, что в разговорном дискурсе разнообразные утвердительные и усилительные частицы, в зависимости от сферы употребления, могут иметь различные прагматические значения. Оба типа частиц, в особенности в начале высказывания, могут служить коннекторами для обозначения семантической связи между частями дискурса.

Ключевые слова: частица, интенсификатор, коннектор, разговорный дискурс. 